\title{
Nutritional and functional properties of coloured rice varieties of South India: a review
}

\author{
Rathna Priya T. S., Ann Raeboline Lincy Eliazer Nelson, Kavitha Ravichandran* and Usha Antony
}

\begin{abstract}
Rice is a major cereal food crop and staple food in most of the developing countries. India stands second in the production of rice next to China. Though almost 40,000 varieties of rice are said to exist, at present, only a few varieties are cultivated extensively, milled and polished. Even if white rice is consumed by most people around the world, some specialty rice cultivars are also grown. These include the coloured and aromatic rice varieties. The nutritional profile of the specialty rice is high when compared to the white rice varieties. The coloured rice, which usually gets its colour due to the deposition of anthocyanin pigments in the bran layer of the grain, is rich in phytochemicals and antioxidants. Rice bran, a by-product of the rice milling industry is under-utilised, is rich in dietary fibre which finds application in the development of functional foods and various other value-added products. Thus, more focus on specialty rice and its by-products will not only save it from becoming extinct but also lead a step forward towards nutrition security of the country as they are abundant in vitamins, minerals and polyphenols.
\end{abstract}

Keywords: Rice, Coloured rice, Polyphenols, Phytochemicals

\section{Introduction}

Rice is a major cereal crop consumed as a staple food by over half of the world's population. Consumption of rice is very high in developing countries and nations in Asia. Almost 95\% of the rice production is done in Asian countries and about half of the world's population consumes it. The cultivation of rice ranks third in the production of agricultural commodity next to sugarcane and maize. It is the predominant dietary energy source of 17 countries in Asia and the Pacific, 9 countries in North and South America and 8 countries in Africa. India is one of the major centres for rice production. The area for rice cultivation in India comprises about 43,388,000 hectares of land [1] and rice contributes to 780 and $689 \mathrm{kcal} / \mathrm{capita} /$ day of the food supply in Asia and India, respectively. Furthermore, India is one of the largest countries in terms of energy consumption from agriculture and rice comprises a major part of it [2].
Rice is rich in genetic diversity, with thousands of varieties grown throughout the world and India is home to 6000 varieties, at present. Originally, India had more than 110,000 varieties of rice until 1970, which were lost during the Green Revolution with its emphasis on monoculture and hybrid crops [3]. Paddy comes in many different colours, including brown, red, purple and even black. The colourful varieties of rice are considered valuable for their health benefits. The unpolished rice with its bran has high nutrient content than milled or polished white rice. However, rice consumers prefer to consume polished white rice, despite the fact that brown rice contains valuable nutrient content [4]. A detailed analysis on the nutrient content of rice suggests that the nutrition value varies depending upon several factors such as the strain or variety (i.e. white, brown, red and black/purple), nutrient quality of the soil in which rice is cultivated, the degree of milling and the method of preparation before consumption.

\footnotetext{
* Correspondence: kavisri9@gmail.com

Centre for Food Technology, Department of Biotechnology, Alagappa

College of Technology, Anna University, Guindy, Chennai-25, India
}

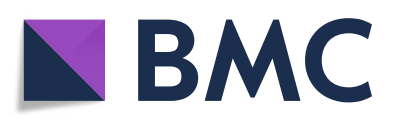

(c) The Author(s). 2019 Open Access This article is distributed under the terms of the Creative Commons Attribution 4.0 International License (http://creativecommons.org/licenses/by/4.0/), which permits unrestricted use, distribution, and reproduction in any medium, provided you give appropriate credit to the original author(s) and the source, provide a link to the Creative Commons license, and indicate if changes were made. The Creative Commons Public Domain Dedication waiver (http://creativecommons.org/publicdomain/zero/1.0/) applies to the data made available in this article, unless otherwise stated. 


\section{Origin and spread of rice}

Oryza sativa, the dominant rice species, is a member of the Poaceae family. Historically, rice was cultivated widely in the river valleys of South and Southeast Asia 10,000 years ago [5] and it is believed to have originated probably in India. Domestication of rice in India is mainly attributed to the Indus valley civilization c. 3000-1500 BC [6]; however, the evidence of rice cultivation in India has been pushed to 4000 years ahead with the discovery of rice grains and early pottery found in the site of Lahuradewa, Uttar Pradesh, situated in the middle Ganges plains dating to c. 6409 BC [7, 8].

Rice is highly adaptable to its environment of growth and this is evident from the fact that it is grown in north-eastern parts of China at latitude $53^{\circ} \mathrm{N}$, on the equator in central Sumatra, and at $35^{\circ} \mathrm{S}$ in New South Wales, Australia. In India, it is grown below sea level in Kerala; most rice-growing areas are present at or near sea level and also, at elevations above $2000 \mathrm{~m}$ in Kashmir. Today, rice is cultivated in all parts of the world except Antarctica [9].

\section{Importance of rice in India}

India ranks second in the production of rice in the world next to China, accounting for $22.5 \%$ of overall world rice production. Rice is India's pre-eminent crop and is the staple food of the people of the eastern and southern parts of the country. Apart from being nutritionally rich, rice has greater significance in India and holds great spiritual and ritual importance. As per Indian tradition, rice is revered as a potent symbol of auspiciousness, prosperity and fertility because of its life-sustaining qualities. Several rituals involving rice are performed during different occasions and festivals. In Tamil Nadu, kolam, a kind of geometric pattern, is drawn using rice flour at the threshold of the houses by women before sunrise. Rice also plays a vital role in wedding ceremonies in India. Dhanpan is a ritual wherein the family of bridegroom sends paddy, betel and/or turmeric to the house of the bride [10]. Rice mixed with turmeric is thrown on the couples during the wedding ceremony as a symbol of prosperity, eternity, continuity and fertility. The father of the bride organises a feast called Bhat (means, boiled rice) for the family and relations of the bridegroom [10]. The brides throw five handfuls of rice before leaving their parents' home after the wedding to wish prosperity and wealth and remain with the family members. The bride enters her new home by pushing a glass or a jar full of rice while, rice is the first food offered to the bridegroom by the bride after marriage. In Tamil Nadu, the groom is offered a special variety of rice named Maappillai Samba to improve fertility [11]. Rice also plays a vital role during the baby shower function, named godh bharai in North India, valaikaapu in Tamil
Nadu and seemandham in Kerala; on the event of birth; at the time of giving first solid food to the baby that is 6 or 7 months old; and during puberty in Kerala and Tamil Nadu. Flattened rice made from a variety called Thavala Kannan is given as offering in Kerala.

Rice also plays a prominent role in cultural celebrations of India, such as the festivals are based on sowing of seeds in the paddy field, transplanting the saplings in the fields, removal of weeds from the fields, harvesting of paddy, thrashing of paddy and storage of paddy [10]. The harvest festivals include Thai Pongal celebrated in the Tamizhian calendar month of Thai (falls in the month of January) in Tamil Nadu; Onam celebrated in the Malayalam month of Chingam (falls in the month of August or September) and Sankranti in Andhra Pradesh and Telangana, Makar Sankranti in Karnataka, Na-Khuwa Bhooj in rural Assam, Nabanna in West Bengal, and Nua khia or Navanna in Odisha; and Bihu in Assam celebrates the harvest of paddy. Thus, rice has not only shaped the history, culture, diet and economy of people but also the growth stage of the rice crop marks the passage of time and season. In India, rice is considered the root of civilization [12].

\section{Production and market demand for rice varieties}

Rice is a fundamental food in many cultural cuisines around the world. According to Ricepedia, more than $90 \%$ of production and consumption of rice in the world occur in Asia and the current share in global rice consumption is around $87 \%$. In African countries, per capita consumption continues to increase than production [13]. The volume of international rice trade has increased almost sixfold, from 7.5 million tonnes annually in the 1960 s to an average of 44.2 million tonnes during 2015-2016.

Based on the global market scenario with respect to rice, the production has increased slightly with years. The use of rice as food remains predominant compared to feed and other uses. The supply and utilisation of rice have also increased slightly (Table 1).

Similarly, rice is a major cereal crop and is consumed as a staple food by the majority of the population in India. India is one of the major centres for the production of rice. Both the Himalayan red rice and the Assam red rice find their place in international trade. The production of rice, wheat and maize has grown steadily over this period and that of rice is the highest followed by wheat (Table 2). In contrast, the production of other grains such as sorghum, pearl millet, finger millet, little millet and coarse cereals have either remained steady or have declined.

Rice is consumed by the rich and poor as well as rural and urban households. The per capita net availability of food grains increased after the Green Revolution, and 
Table 1 Summary of the global rice market [14]

\begin{tabular}{lllll}
\hline & $2014-2015$ & $2015-2016$ & $2016-2017$, estimate & 2017-2018, forecast \\
& Million tonnes, milled equivalents & & 502.2 \\
\hline Production & 490.9 & 491.9 & 501.2 & 718.4 \\
Supply & 709.2 & 703.8 & 712.0 & 503.5 \\
Utilisation & 494.3 & 492.5 & 497.9 & 406.7 \\
Food use & 397.2 & 395.6 & 400.9 & 17.5 \\
Feed use & 18.0 & 18.2 & 17.8 & 79.4 \\
Other uses & 79.2 & 78.7 & 79.2 & 7 \\
\hline
\end{tabular}

rice is a part of the balanced diet along with vegetables, pulses, eggs, meat and fruits. The per capita net availability of rice increased to $69.3 \mathrm{~kg} /$ year in 2017 from $58.0 \mathrm{~kg} /$ year in $1951[15,16]$. Although rice is widely consumed, with years, the expenditure on cereals decreased from $26.3 \%$ in $1987-1988$ to $12.0 \%$ in $2011-$ 2012 and from $15 \%$ in $1987-1988$ to $7.3 \%$ in $2011-2012$ in rural and urban households, respectively. This overall dip in the expenditure may be due to the fact that more money is spent on non-food items in both rural and urban households [16].

\section{Rice varieties}

Among the 40,000 varieties of rice cultivated worldwide, only two major species are cultivated widely-Oryza sativa or the Asian rice and Oryza glaberrima or the African rice. The cultivation of Oryza sativa is practised worldwide; however, the cultivation of the Oryza glaberrima is confined to Africa [17].

Oryza sativa has two major subspecies: the Indica, long-grain rice and the Japonica, round-grain rice. Japonica rice is mainly cultivated and consumed in Australia, China, Taiwan, Korea, the European Union, Japan, Russia, Turkey and the USA. Indica rice varieties are grown widely in Asia [17]. These varieties also comprise of the fragrant ones which are priced as premium. The principal fragrant varieties are Hom Mali from Thailand and the various types of Basmati exclusively grown on the Himalayan foothills of India (in the states of Haryana and Punjab) and Pakistan (in the state of Punjab) [18].

The Indian rice varieties cultivated widely are Basmati, Joha, Jyothi, Navara, Ponni, Pusa, Sona Masuri, Jaya, Kalajiri (aromatic), Boli, Palakkad Matta, etc. The coloured variety includes Himalayan red rice; Matta rice, Kattamodon, Kairali, Jyothy, Bhadra, Asha, Rakthashali of Kerala; Red Kavuni, Kaivara Samba, Mappillai Samba, Kuruvi Kar, Poongar of Tamil Nadu, etc.

\section{The shelf life of rice}

In general, it is recommended to store rice in the form of paddy rather than as milled rice, since the husk provides protection against insects and helps prevent quality deterioration. Rice can be stored for long periods only if the following three conditions are met and maintained: (1) the moisture levels of grains, $14 \%$ or less and that of seeds must be $12 \%$ or less; (2) grains must be well protected from insects, birds and rodents; and (3) grains must be protected from rains or imbibing moisture from the atmosphere. In addition to its nutritive and medicinal properties, red rice and black rice possess several other special features and the most common one is their

Table 2 Production of cereals in India from 2009 to 2017 [1]

\begin{tabular}{llllllllll}
\hline Crop & 2009-2010 & 2010-2011 & 2011-2012 & 2012-2013 & 2013-2014 & 2014-2015 & 2015-2016 & 2016-2017, estimates \\
& Million tonnes & & & & & & & \\
Rice & 89.09 & 95.98 & 105.30 & 105.24 & 106.65 & 105.48 & 104.41 & 109.15 \\
Wheat & 80.80 & 86.87 & 94.88 & 93.51 & 95.85 & 86.53 & 92.29 & 97.44 \\
Sorghum & 6.70 & 7.00 & 5.98 & 5.28 & 5.54 & 5.45 & 4.24 & 4.74 \\
Pearl millet & 6.51 & 10.37 & 10.28 & 8.74 & 9.25 & 9.18 & 8.07 & 9.86 \\
Maize & 16.72 & 21.73 & 21.76 & 22.26 & 24.26 & 24.17 & 22.57 & 26.14 \\
Finger millet & 1.89 & 2.19 & 1.93 & 1.57 & 1.98 & 2.06 & 1.82 & 1.43 \\
Small millets & 0.38 & 0.44 & 0.45 & 0.44 & 0.43 & 0.39 & 0.39 & 0.44 \\
Barley & 1.35 & 1.66 & 1.62 & 1.75 & 1.83 & 1.61 & 1.44 & 1.79 \\
Coarse cereals & 33.55 & 43.40 & 42.01 & 40.04 & 43.29 & 42.86 & 38.52 & 44.39 \\
Total & 203.45 & 226.25 & 242.20 & 238.79 & 245.79 & 234.87 & 235.22 & 250.98 \\
\hline
\end{tabular}


resistance to insects and pests during storage than brown rice. From the cultivation point of view, red rice possesses resistance to drought, flood, submergence, alkalinity, salinity, and resistance to pests and diseases [19].

\section{Structure of rice grain}

The paddy (also, rough rice or rice grain) consists of the hull, an outer protective covering, and the fruit or rice caryopsis (brown or dehusked rice) [20]. Rice primarily consists of carbohydrates, proteins and small quantities of fat, ash, fibre and moisture. Vitamins and minerals are largely confined to the bran and germ [21].

The polished white rice, usually consumed, is the highly refined version of raw rice. The processing and milling of raw rice take away significant parts of the grain, namely the bran and the germ. Both bran and germ are rich in dietary fibre as well as nutrients that are beneficial for human health. Further, if white rice undergoes additional polishing, its aleurone layer gets removed leading to loss of more nutrients, as this layer is rich in vitamin $B$, proteins, minerals and essential fats.

In this aspect, the coloured rice finds an advantage as a healthier alternative to white rice. Coloured rice varieties and brown rice varieties have the same harvesting process apart from possessing similar nutritional profiles. These varieties are usually either dehulled or partially hulled with the bran and germ intact. Brown rice is found worldwide, while red rice is confined to the Himalayas, Southern Tibet, and Bhutan, as well as parts of North East and South India. After the removal of husk, brown rice still consists of few outer layers-the pericarp, seed-coat and nucellus; the germ or embryo; and the endosperm. The endosperm consists of the aleurone layer, the subaleurone layer and the starchy or inner endosperm (Fig. 1). The aleurone layer encloses the embryo. Pigments are confined to the pericarp layer [20].

The hull (also, husk) constitutes about $20 \%$ of the rough rice weight, but values range from 16 to $28 \%$. The aleurone layer varies from one to five cell layers; it is thicker at the dorsal than at the ventral side and thicker in short-grain than in long-grain rice [23]. The aleurone and embryo cells are rich in protein and lipid bodies [24].

The different layers of rice contain different quantities of nutrients. The bran layer is rich in dietary fibre, minerals and vitamin B complex while the aleurone layer contains the least. The endosperm of rice is rich in carbohydrate and also contains a reasonable amount of digestible protein, with favourable amino acid profile than other grains [25].

\section{Rice processing}

Processing of rice mainly involves milling of rice which converts paddy into rice by removing the hull and all or

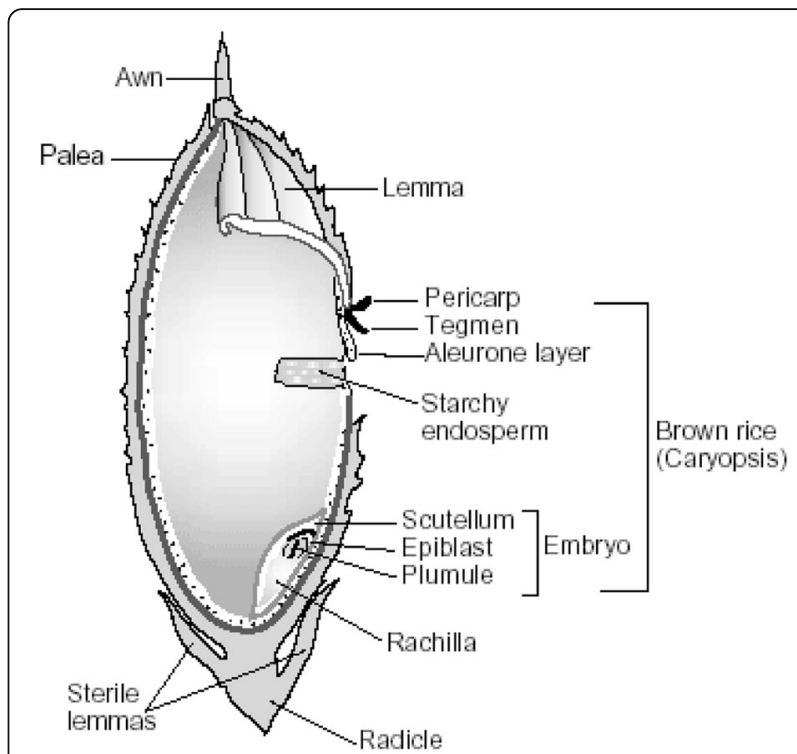

Fig. 1 Structure of rice grain (Copyright: FAO) [22]. Paddy consists of the husk, bran, aleurone layer, starchy endosperm and embryo. Brown rice is semi-polished, so it retains embryo while white rice is more polished than brown rice, lacking bran, aleurone and embryo. The removal of bran, aleurone and embryo provides aesthetic appeal to rice and improves shelf life; however, it also removes nutrients and minerals found in the grain

part of the bran layer. Milling of rice is a crucial stage and the objective of milling is to remove the husk and bran so as to produce an edible white rice kernel that is free from impurities.

Rabbani and Ali [26] report that as a result of processing, some essential nutrients like thiamine and vitamin B are lost. The milling process followed by polishing destroys $67 \%$ of the vitamin $B_{3}, 80 \%$ of vitamin $B_{1}, 90 \%$ of vitamin $B_{6}, 50 \%$ of manganese and phosphorus, $60 \%$ of the iron, and all of the dietary fibre, as well as the essential fatty acids present in the raw unmilled variety.

The rough rice (also, paddy) on milling produces brown rice, milled rice, germ, bran, broken and husk. Each of these has unique properties and can be used in numerous ways. The extent of value addition in rice and rice products depends upon the utilisation pattern of these components directly or as derivatives. For coloured rice varieties, only the first three steps of milling, namely, pre-cleaning, dehusking and separation, are applied and bran and germ are left intact.

\section{Nutritional information White rice}

Raw, long-grain white rice is a good source of carbohydrates, calcium, iron, thiamine, pantothenic acid, folate and vitamin $\mathrm{E}$ when compared with maize, wheat and potatoes. It does not contain vitamin $\mathrm{C}$, vitamin $\mathrm{A}$, beta- 
carotene, lutein and zeaxanthin. It is also notably low in dietary fibre.

\section{Coloured rice}

Brown rice retains its bran layer (containing vitamins, minerals and fibre), as this has not been polished more to produce white rice. The coloured rice varieties are either semi-polished or unpolished (Fig. 2). Red-coloured rice varieties are known to be rich in iron and zinc, while black rice varieties are especially high in protein, fat and crude fibre. Red and black rice get their colour from anthocyanin pigments, which are known to have free radical scavenging and antioxidant capacities, as well as other health benefits.

Brown rice is highly nutritious. It has low calorie and has a high amount of fibre. Furthermore, it is a good source of magnesium, phosphorus, selenium, thiamine, niacin, vitamin $B_{6}$ and an excellent source of manganese. Brown rice and rough rice are rich in vitamins and minerals; this is due to the fact that the vitamins are confined to the bran and husk of the paddy. Rice bran and husk contain a higher amount of calcium, zinc and iron (Table 3 ).

Rice is rich in glutamic and aspartic acids but has a lower amount of lysine. The antinutritional factors that are concentrated mainly in the bran are phytate, trypsin inhibitors, oryzacystatin and haemagglutinin-lectin [25].

\section{Moisture}

The moisture content plays a significant role in determining the shelf life of foods [29]. Xheng and Lan [30] report that moisture influences the milling characteristics and the taste of cooked rice. The differences in genetic makeup and the climatic conditions in which they are cultivated determine the moisture content in rice varieties. As seen from Table 4, the moisture content of the red rice varieties is variable from 9.3 to $12.94 \%$, the moisture content of brown rice and milled rice is lower than other rice varieties.

\section{Protein}

Protein is the second major component next to starch; it influences the eating quality and the nutritional quality of rice. In India, the dietary supply of rice per person per day is $207.9 \mathrm{~g}$, this provides about $24.1 \%$ of the required dietary protein [2]. Rice has a wellbalanced amino acid profile due to the presence of lysine, in superior content to wheat, corn, millet and sorghum and thus makes the rice protein superior to other cereal grains [36]. The lysine content of rice protein is between 3.5 and $4.0 \%$, making it the highest among cereal proteins. The endosperm protein comprises of $15 \%$ albumin (water soluble), globulin (salt soluble), 5-8\% prolamin (alcohol soluble), and the rest glutelin (alkali soluble) [27].

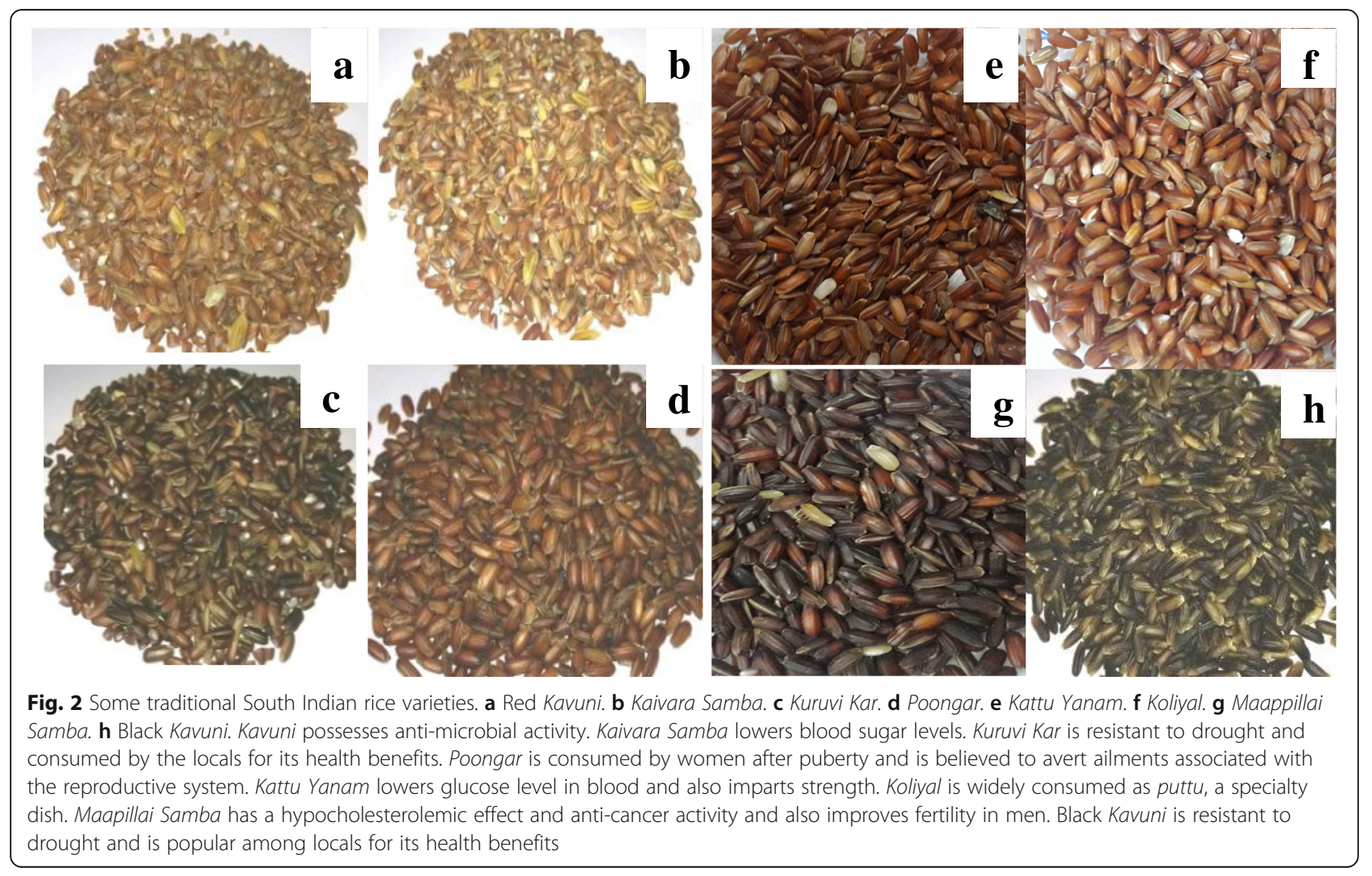


Table 3 Vitamin and mineral content of rough rice and its milling fractions at $14 \%$ moisture $[27,28]$

\begin{tabular}{llllllllll}
\hline Rice fraction & Thiamine $(\mathrm{mg})$ & Riboflavin $(\mathrm{mg})$ & Niacin $(\mathrm{mg})$ & a-Tocopherol $(\mathrm{mg})$ & Calcium $(\mathrm{mg})$ & Phosphorus $(\mathrm{g})$ & Phytin $(\mathrm{g})$ & Iron $(\mathrm{mg})$ & Zinc $(\mathrm{mg})$ \\
\hline Rough rice & $0.26-0.33$ & $0.06-0.11$ & $2.9-5.6$ & $0.90-2.00$ & $10.0-80.0$ & $0.17-0.39$ & $0.18-0.21$ & $1.4-6.0$ & $1.7-3.1$ \\
Brown rice & $0.29-0.61$ & $0.04-0.14$ & $3.5-5.3$ & $0.90-2.50$ & $10.0-50.0$ & $0.17-0.43$ & $0.13-0.27$ & $0.2-5.2$ & $0.6-2.8$ \\
Milled rice & $0.02-0.11$ & $0.02-0.06$ & $1.3-2.4$ & $0.075-0.30$ & $10.0-30.0$ & $0.08-0.15$ & $0.02-0.07$ & $0.2-2.8$ & $0.6-2.3$ \\
Rice bran & $1.20-2.40$ & $0.18-0.43$ & $26.7-49.9$ & $2.60-13.3$ & $30.0-120.0$ & $1.1-2.5$ & $0.9-2.2$ & $8.6-43.0$ & $4.3-25.8$ \\
Rice hull & $0.09-0.21$ & $0.05-0.07$ & $1.6-4.2$ & 0 & $60.0-130.0$ & $0.03-0.07$ & 0 & $3.9-9.5$ & $0.9-4.0$ \\
\hline
\end{tabular}

The coloured rice has high protein content than polished white rice due to the presence of bran. The Srilankan and Chinese varieties have higher protein content than the Indian varieties (Table 4). Rice bran proteins are rich in albumin than endosperm proteins. The aleurone protein bodies contain $66 \%$ albumin, $7 \%$ globulin and 27\% prolamin and glutelin [37].

\section{Fat}

The fat present in rice is a good source of linoleic acid and other essential fatty acids. The rice does not contain cholesterol [36]. The lipids or fats in rice are mainly confined to the rice bran (20\%, dry basis). It is present as lipid bodies in the aleurone layer and bran. The core of the lipid bodies is rich in lipids and the major fatty acids are linoleic, oleic and palmitic acids [38, 39]. Starch lipids present in rice is composed of monoacyl lipids (fatty acids and lysophosphatides) complexed with amylose [40]. The amount of fat present in various fractions of rice and red rice indicate that red rice varieties from Sri Lanka and India have about $1 \%$ fat, while the China red rice has almost doubled this value (Table 4).

\section{Fibre}

The presence of fibre in the diet increases the bulk of faeces, which has a laxative effect in the gut. The fibre content is $0.5-1.0 \%$ for well-milled rice [41]. Arabinoxylans, along with $\beta$-d-glucan, are the major component of soluble dietary fibre in rice. In addition, rhamnose, xylose, mannose, galactose and glucose are also present in soluble dietary fibre. Insoluble dietary fibre is made up of cellulose, hemicellulose, insoluble $\beta$-glucan and arabinoxylans. However, the quantity and amount of non-starch polysaccharide depend upon the rice cultivar, the degree of milling and water solubility [42]. Among the red rice varieties, Chak-hao amubi (Manipur black rice) has a significantly lower content of crude fibre (Table 4).

\section{Ash}

The variation in ash content of different cultivars of rice may be due to genetic factors or the mineral content of the soil [43]. The zinc and iron content of red rice is

Table 4 Proximate composition of rice based on its milling fractions and coloured varieties

\begin{tabular}{|c|c|c|c|c|c|c|c|}
\hline Rice & Moisture & Protein (g) & Fat (g) & Crude fibre (g) & Crude ash (g) & Carbohydrates (g) & References \\
\hline Rough rice & 14.0 & $5.8-7.7$ & $1.5-2.3$ & $7.2-10.4$ & $2.9-5.2$ & $64.0-73.0$ & {$[25,27,31]$} \\
\hline Brown rice & $7.1-11.6$ & $5.9-11.0$ & $1.6-2.8$ & $0.22-0.95$ & $0.43-2.34$ & $71.31-84.75$ & {$[4]$} \\
\hline Raw hand pound rice & 13.3 & 7.5 & 1.0 & 0.6 & 0.9 & 76.7 & {$[32]$} \\
\hline Milled rice, raw & $9.93 \pm 0.75$ & $9.16 \pm 0.75$ & $1.24 \pm 0.08$ & $1.04 \pm 0.18$ & $4.43 \pm 0.54$ & $74.80 \pm 0.85$ & {$[33]$} \\
\hline Parboiled rice & $10.09 \pm 0.43$ & $7.81 \pm 0.63$ & $0.55 \pm 0.08$ & $0.65 \pm 0.08$ & $3.74 \pm 0.36$ & $77.16 \pm 0.76$ & [33] \\
\hline White rice (polished) & $7.01-11.2$ & $5.8-7.7$ & $0.5-2.3$ & $0.01-0.78$ & $0.12-1.22$ & $76.8-86.56$ & {$[4]$} \\
\hline Rice bran & 14.0 & $11.3-14.9$ & $15.0-19.7$ & $7.0-11.4$ & $6.6-9.9$ & $34.0-62.0$ & {$[27,28,31]$} \\
\hline Rice hull & 14.0 & $2.0-2.8$ & $0.3-0.8$ & $34.5-45.9$ & $13.2-21.0$ & $22.0-34.0$ & \\
\hline Red rice & $9.3-13.1$ & $7.16-10.85$ & $1.15-3.19$ & $0.28-0.61$ & $0.82-1.5$ & $70.75-81.29$ & [34] \\
\hline Sri Lanka red rice & $12.94 \pm 0.03$ & $9.63 \pm 0.04$ & $1.15 \pm 0.03$ & $2.82 \pm 0.55$ & $0.82 \pm 0.14$ & $75.45 \pm 0.09$ & \\
\hline China red rice & $11.90 \pm 0.20$ & $9.72 \pm 0.04$ & $2.35 \pm 0.03$ & $2.52 \pm 0.24$ & $1.37 \pm 0.02$ & $74.66 \pm 0.17$ & \\
\hline $\begin{array}{l}\text { Chak-hao amubi } \\
\text { (Manipur black rice) }\end{array}$ & $11.6 \pm 0.04$ & $8.8 \pm 0.05$ & $1.0 \pm 0.07$ & $0.3 \pm 0.06$ & $0.5 \pm 0.07$ & $78.0 \pm 0.03$ & {$[35]$} \\
\hline $\begin{array}{l}\text { Maappillai Samba } \\
\text { (Tamil Nadu red rice) }\end{array}$ & $10.3 \pm 0.73$ & $8.16 \pm 0.45$ & $0.918 \pm 0.13$ & $2.5 \pm 0.28$ & $2.26 \pm 0.72$ & $75.86 \pm 2.31$ & $\begin{array}{l}\text { (Rathna Priya TS. Phytochemical } \\
\text { Composition and Functional } \\
\text { Properties of Red Rice and its } \\
\text { Applications in Product } \\
\text { Development. Masters Thesis, } \\
\text { Anna University, Chennai, } \\
\text { India, Unpublished). }\end{array}$ \\
\hline
\end{tabular}


two to three times higher than that of white rice [44]. The most common minerals found in rice include calcium, magnesium, iron and zinc (Table 3).

The proximate composition of rice and its fractions are influenced by the kind of rice and degree of milling, as milling completely or partially removes the bran layer, aleurone layer and embryo. Thus, variation occurs in the nutrition content between the rice fractions of the same rice variety. The variations can be found in the amount of fats, fibre and minerals present in the grain.

\section{Phytochemical composition}

The non-nutritive plant chemicals that have a protective or disease-preventing property are known as phytochemicals. The phytochemical compounds are mainly accumulated in the pericarp and bran of the rice kernel. They prevent oxidative damage in foods and also have a wide spectrum of beneficial biological activities.

Phytochemicals present in rice can be divided into the following sub-groups namely carotenoids, phenolics, alkaloids, nitrogen and organo-sulphur containing compounds. Phenolic compounds are further sub-grouped as phenolic acids, flavonoids, coumarins and tannins. Anthocyanins, the major pigment responsible for the colour of red and black rice, are a kind of flavonoids. Maapillai Samba, a kind of red rice from Tamil Nadu, has the highest amount of total polyphenolic compounds and anthocyanin content than the varieties from Sri Lanka, China red rice and Manipur black rice (Table 5).

The pigmented cereal grains, such as red and purple/ black rice, have phytochemical compounds in higher amounts than non-pigmented varieties. The phytochemicals such as cell wall-bound phenolics and flavonoids are gaining more interest as these compounds can be broken down by digestive enzymes and gut microflora, and as a result, they can be easily absorbed into the body [45].

The coloured rice bran contains anthocyanins that possess inhibition of reductase enzyme and anti-diabetic activities [46]. The reductase inhibitors possess antiandrogen effects and are used in the treatment of benign prostatic hyperplasia and to lower urinary tract symptoms. $\beta$-sitosterol present in Maappillai Samba (Fig. 2g) has a hypocholesterolemic effect, improves fertility and also heals colon cancer. Furthermore, stigmasterol found in this variety is a precursor in the production of semisynthetic progesterone [11].

Garudan Samba contains 9,12-octadecadienoic acid ( $Z$, $Z$ ) which has the potential to act as hypocholesterolemic, anti-arthritic, hepatoprotective, 5-alpha-reductase inhibitor, anti-histaminic, anti-coronary and anti-androgenic effects. In addition to these compounds, it also contains several other bioactive compounds [47].

3-Cyclohexene-1-methanol and $\alpha, \alpha, 4$-trimethyl- present in red Kavuni (Fig. 2a) possess the anti-microbial activity, and also, 3-hydroxy-4 methoxy benzoic acid is used as a precursor for the synthesis of morphine. In addition to these compounds, fatty acid esters and fatty acids such as dodecanoic acid, ethyl ester (lauric acid ester) and octadecanoic acid are present. Among these bioactive compounds, octadecanoic acid and ethyl esters increase low-density lipoprotein (LDL) cholesterol in the human body [48].

\section{Health benefits}

Depending upon the flavours, culinary needs, availability and its potential health benefits, people choose different varieties of rice. Rice has the ability to provide fast and instant energy. Brown rice and red rice are great sources of fibre, B vitamins, calcium, zinc and iron, manganese, selenium, magnesium and other nutrients. The red and black rice variety gets its rich colour from a group of phytochemicals called anthocyanins, which are also found in deep purple or reddish fruits and vegetables.

\section{Diabetes mellitus}

Unlike white polished rice, brown rice releases sugars slowly thus helping to stabilise blood sugar in a sustained manner. This trait makes it a better option for people who are suffering from diabetes mellitus. Further, studies in Asia have shown a relationship between the consumption of white rice and risk of type 2 diabetes. Dietary fibres reduce the absorption of

Table 5 Total polyphenolic content and total anthocyanin content of red rice varieties

\begin{tabular}{|c|c|c|c|}
\hline Varieties & $\begin{array}{l}\text { Total phenolic content } \\
\left(\mathrm{mg} 100^{-1} \mathrm{~g}\right)\end{array}$ & $\begin{array}{l}\text { Total anthocyanin content } \\
\text { (mg cyanidin-3-glucoside } \\
\text { equivalent } 100^{-1} \mathrm{~g} \text { ) }\end{array}$ & References \\
\hline Sri Lanka red rice & $118.47 \pm 11.52$ & $0.35 \pm 0.02$ & [34] \\
\hline China red rice & $253.34 \pm 5.14$ & $1.00 \pm 0.01$ & \\
\hline Chak-hao amubi (Manipur black rice) & 579.00 & 1.81 & [35] \\
\hline Maapillai Samba (Tamil Nadu red rice) & $294.71 \pm 33.9$ & $6.52 \pm 2.73$ & $\begin{array}{l}\text { (Rathna Priya TS. Phytochemical } \\
\text { Composition and Functional } \\
\text { Properties of Red Rice and its } \\
\text { Applications in Product Development. Masters Thesis, } \\
\text { Anna University, Chennai, India, Unpublished). }\end{array}$ \\
\hline
\end{tabular}


carbohydrates by providing an enclosure to the food, hindering the action of hydrolytic enzymes in the small intestine on food, and increasing the viscosity of food in the intestine [49]. This plays a vital role in reducing the GI of food thereby preventing the risk of diabetes type 2 [50]. Proanthocyanidins present in red rice provide protection against type 2 diabetes [51]. Similarly, anthocyanins present in black rice is said to have a hypoglycemic effect [52].

\section{Cancer}

Brown rice is rich in manganese and selenium, which play a vital role against free radicals, which acts as a major cancer-causing agent. Due to the presence of these elements and high dietary fibre, brown rice is associated with a lowered risk of cancer. Studies have also correlated the use of whole grains like brown rice with lowered levels of colon cancer. This may be related to its high fibre content, as fibre gets attached to carcinogenic substances and toxins helps to eliminate them from the body, and also keep them away from attaching to the cells in the colon. Proanthocyanins, present in red rice, modulate the inflammatory response and protect against some cancers [51]. Similarly, anthocyanins which are found abundantly in black rice have anti-carcinogenic properties based on epidemiological and in vivo animal and human-based studies [53].

\section{Cardiovascular disease}

Brown rice may help in lowering the risk of metabolic syndrome, while metabolic syndrome itself is a strong predictor of cardiovascular disease. Red rice contains magnesium that prevents the risk of heart attacks [54]. Various high-fat diet-induced risk factors for cardiovascular disease were ameliorated by anthocyanin-rich extracts from black rice in rat models [55].

\section{Cholesterol}

Brown rice contains naturally occurring bran oil, which helps in reducing LDL forms of cholesterol. Intake of black rice has found to eliminate reactive oxygen species (ROS) such as lipid peroxide and superoxide anion radicals and lower cholesterol levels due to the presence of compounds such as anthocyanins, polyphenolic compounds, flavonoids, phytic acid, vitamin $E$ and $\gamma$-oryzanol $[56,57]$. Modulation of inflammatory responses by proanthocyanidins in red rice provided protection from cardiovascular disease [51]. Based on these studies, it is evident that whole grains can lower the chances of arterial plaque buildup, thus reducing the chances of developing heart disease.

\section{Hypertension}

Both brown and red rice have high magnesium content than white rice. Magnesium is an important mineral that plays a vital role in the regulation of blood pressure and sodium balance in the body [54].

\section{Obesity}

Rice varieties such as brown, red and black rice are rich in fibre and have the ability to keep healthy bowel function and metabolic function. Anthocyanins present in red rice have properties that can help in weight management [54].

\section{Allergy}

Rice protein is hypoallergenic; products from other plant sources such as soy and peanut and animal sources like eggs and milk are a good source of proteins, yet they may cause allergy when consumed. Rice protein provides a solution to this problem because it is hypoallergenic. Furthermore, the anthocyanins present in red rice also have the property to reduce allergy [54].

\section{Medicinal uses of coloured rice}

Among several types of rice, few varieties are used to treat ailments. Every variety of rice is unique in its properties, so the treatment of diseases using rice is not limited to a single variety alone. Many different varieties of rice are employed in treating ailments because of their different properties and characteristics. According to practitioners of Ayurveda, rice creates balance to the humours of the body. Rice enriches elements of the body; strengthens, revitalises and energises the body by removing toxic metabolites; regulates blood pressure; and prevents skin diseases and premature ageing. Rakthasali (a kind of red rice) is efficient in subduing disturbed humours of the body and good for fevers and ulcers; improves eyesight, health, voice and skin health; and increases fertility [58-61]. In Ayurveda, Sali, Sashtika and Nivara rice are used to treat bleeding from haemorrhoids (piles); Sali rice is used to treat burns and fractures; Nivara rice is used to treat cervical spondylitis, paralysis, rheumatoid arthritis, neuromuscular disorders, psoriasis, skin lesions, reduce backache, stomach ulcers and snakebite; and Nivara rice is also used in the preparation of weaning food for underweight babies [58, 62].

Rice water prepared by soaking rice in water or boiling rice in excess water is used to control diseases. In Ayurvedic preparations, rice varieties such as Mahagandhak ras, Kamdudha ras, Sutsekhar ras, Amritanav ras, Swarnmalti ras, Pradraripu ras, Laghumai ras, Dughdavati, Pradaknasak churna, Pushpnag churna, Sangrahat bhasm and Mukta sukti are used to control ailments such as vaginal and seminal discharges, diarrhoea, constipation and dysentery [58]. Red rice 
varieties are known to be used in the treatment of ailments such as diarrhoea, vomiting, fever, haemorrhage, chest pain, wounds and burns [63]. Matali and Lal Dhan are used for curing blood pressure and fever in Himachal Pradesh. Another red rice variety called Kafalya from the hills of Himachal Pradesh and Uttar Pradesh is used in treating leucorrhoea and complications from abortion [64]. Kari Kagga and Atikaya from Karnataka are used for coolness and also as a tonic, whereas Neelam Samba of Tamil Nadu is used for lactating mothers [65]. Kuruvi Kar is resistant to drought and consumed by the locals for its health benefits [66]. Raktasali is efficient in subduing deranged humours $[60,61]$. It was also regarded as a good treatment for ailments such as fevers and ulcers. It is also believed that it improves eyesight and voice; acts as diuretic, spermatophytic, cosmetic and tonic; and was also antitoxic [59].

\section{Traditional food and its importance}

Ayurvedic treatises mention red rice as a nutritive food and medicine, so the red rice is eaten as a whole grain. Red rice varieties such as Bhama, Danigora, Karhani, Kalmdani, Ramdi, Muru, Hindmauri and Punaigora of Jharkhand and Chattisgarh are rich in nutrition and provide energy and satiety for a whole day [67, 68]. Traditionally, various foods such as pongal, puttu, adai, appam, idli, dosai, idiyappam, adirasam, kozhukattai, modakam, payasam, semiya, uppuma, flaked rice, puffed rice, etc. are prepared and consumed. In Tamil Nadu and Kerala, paddy is parboiled prior to milling. This hydrothermal process facilitates the migration of nutrients such as vitamins and minerals from the bran and the aleurone layer to the endosperm [69]. Rice takes the place of major cereal consumed in the South Indian diet while it is wheat that holds the position in North Indian diet. Dosai, idli, pongal, appam, semiya, uppuma, kichadi and idiyappam are prepared and consumed for breakfast along with wide varieties of chutney. The specialty dish called puttu made from rice is also prepared and consumed for breakfast. The lunch of South India is a combination of cooked parboiled rice, poriyal, eggs, meat, sambar, dal curry, rasam, pappad, moore (buttermilk) or curd and/or dessert, payasam. The dinner usually consists of idli, dosai, idiappam, cooked rice and curries. Various other dishes are also prepared from rice and include biryani, pulao, fried rice, curd rice, tamarind rice, sambar rice, jeera rice, lemon rice, coconut rice, etc. In Tamil Nadu, appams and idlis are also made using the red rice. Koliyal and Garudan Samba (Kaadai Kazhuththaan) of Tamil Nadu are used in the preparation of a specialty dish called puttu [47].
Flatbread and chapatti are made from red Gunja and glutinous rice is used in making puttu, a South Indian meal [70]. Several products such as cookies, murruku (a type of South Indian snack), are also made using the various coloured rice varieties.

Rice also plays a major role in festivals celebrated in India. The harvest festivals are celebrated with several delicacies made from freshly harvested paddy. In Tamil Nadu, sarkarai pongal is made from raw rice, green gram, milk and jaggery; in Assam, fried rice balls named ghila pitha are prepared and consumed; in West Bengal, traditional Bengali delicacies are made from freshly harvested rice and jaggery, the most famous one is home-made sweets from rice pitha and karpursal or banapuli, and Basmati rice is also used to make Bengali paish.

Parboiled red rice widely consumed in Kerala includes Thondi, Matta, Paal Thondi, Kuruva, Chitteni and Chettadi. Seeraga Samba is an aromatic rice variety consumed widely in Tamil Nadu and Kerala; it is known as 'Basmati of South India' and used in the preparation of biryani. Similarly, Jatu of Kulu valley, Ambemohar of Maharastra, Dubraj of Madhya Pradesh, Joha of Assam, Kamod of Gujarat, Badshah bhog of West Bengal and Odisha, Radhunipagla of West Bengal, Katrini and Kalanamak of Uttar Pradesh and Bihar, Gandha samba of Kerala, Kalajira of Odisha and Chakhao varieties of Manipur are prized for its aroma [64, 67].

Today, the spotlight is on the increased production of these traditional varieties, promoting the consumption among the younger generation and production of nutritious and novel value-added products from coloured rice.

\section{Conclusion}

Although India is home to traditional red rice varieties and their use has been common among the practitioners of traditional medicine and communities as part of their cultural heritage, their functional effects and health benefits in terms of modern scientific methodology are far and few. Due to the insufficient availability of data, the beneficial properties of these varieties still remain unknown to a majority of the population. So, to leverage their health benefits, extensive research on these native coloured varieties by the stakeholders needs to be promoted so that they are available to consumers as a part of the daily diet or specialty functional foods.

\section{Acknowledgements}

The authors wish to thank the anonymous reviewer(s) for their suggestions.

\section{Authors' contributions}

RP initiated the idea of the article and authored all sections of the article except sections on medicinal uses of coloured rice, traditional food products and value-added products and new products. ARLEN authored 
sections on medicinal uses of coloured rice, traditional food products and value-added products and new products; co-authored other sections of the article KR co-authored the sections on the importance of rice in India, rice processing, production and demand of rice varieties, origin and spread of rice and value-added products and new products; and provided critical inputs to revise the manuscript. UA co-authored the sections on structure of grain, nutrition, health benefits and traditional food products; and provided critical inputs to revise the manuscript. All the authors read and approved the final manuscript.

\section{Funding}

Not applicable

\section{Availability of data and materials}

Not applicable

\section{Competing interests}

The authors declare that they have no competing interests.

Received: 21 January 2019 Accepted: 12 September 2019

Published online: 21 October 2019

\section{References}

1. Agricultural Statistics Division, Third advance estimates of production of food grains for 2016-17, Department of Agriculture, Cooperation and Farmers Welfare, India. https://eands.dacnet.nic.in/Advance_Estimate/3rd_ Adv_Estimates2016-17_Eng.pdf. Accessed 20 Nov 2018.

2. Kennedy G, Burlingame B, Nguyen VN. Nutritional contribution of rice and impact of biotechnology and biodiversity in rice-consuming countries, Food and Agriculture Organization of the United Nations. http://www.fao.org/3/ Y4751E/y4751e05.htm. Accessed 26 June 2019.

3. The Hindu, The Hindu Group (2012), 'From 1,10,000 varieties of rice to only 6,000 now.' http://www.thehindu.com/news/national/karnataka/ from-110000-varities-of-rice-to-only-6000-now/article3284453.ece. Accessed 5 Jan 2019.

4. Devi GN, Padmavathi G, Babu VR, Waghray K. Proximate nutritional evaluation of rice (Oryza sativa L.). J Rice Res. 2015;8(1):23-32.

5. Gnanamanickam SS. Rice and its importance to human life. In: Biological Control of Rice Diseases. Progress in Biological Control 2009;(8):1-11.

6. Possehl GL. The Indus Civilization: a contemporary perspective. AltaMira Press. CA; Oxford: Walnut Creek; 2002.

7. Fuller DQ, Qin L, Harvey E. Evidence for a late onset of agriculture in the lower Yangtze region and challenges for an archaeobotany rice. In: Sanchez-Mazas A, Blench R, Ross MD, Peiros I, Lin M, editors. Past Human Migrations in East Asia, Matching Archaeology, Linguistics and Genetics. London: Routledge; 2007. p. 40-83.

8. Tewari R, Srivastava RK, Saraswat KS, Singh IB, Singh KK. Early farming at Lahuradewa. Pragdhara. 2008;18:347-73.

9. Yosida S. Climatic environment and its influence. In: Fundamentals of rice crop science. Manila: International Rice Research Institute; 1981. p. 65.

10. Ahuja SC, Ahuja U. Rice in religion and tradition. $2^{\text {nd }}$ International Rice Congress. 2006. https://www.researchgate.net/publication/321334487. Accessed 23 May 2019.

11. Sulochana S, Singaravadivel K. A study on phytochemical evaluation of traditional rice variety of Tamil Nadu -'Maappillai Samba' by GC-MS. International Journal of Pharma and Biosciences. 2015;6(3):606-11.

12. Gomez KA. Rice, the Grain of culture. Siam Society Lecture Series, The Siam Society, Thailand. 2001. https://www.thairice.org/html/article/pdf_files/Rice_ thegrain_of_Culture.pdf. Accessed 10 June 2018.

13. Ricepedia, CGIAR, IRRI, Philippines. Rice as a Crop. www.ricepedia.org/riceas-a-crop. Accessed 10 Jan 2018.

14. Food and Agricultural Organisation of the United Nations. Rice Market Monitor FAO. 2017. http://www.fao.org/3/l8317EN/I8317EN.pdf. Accessed 20 Oct 2018.

15. Department of Agriculture, Cooperation and Farmers Welfare. Ministry of Agriculture, India. 2017. http://agricoop.nic.in/sites/default/files/pocketbook_ 0.pdf. Accessed 2 Mar 2019.

16. Directorate of Economics and Statistics (DES), Ministry of Agriculture, India. 2014. https://eands.dacnet.nic.in/PDF/Glance-2016.pdf. Accessed 20 Nov 2018.
17. Ricepedia, CGIAR, IRRI, Philippines. Cultivated rice species. http:// ricepedia.org/rice-as-a-plant/rice-species/cultivated-rice-species. Accessed 10 Jan 2018.

18. Calpe C. Rice International Commodity Profile. Food and Agricultural Organisation of the United States. 2006. http://www.fao.org/fileadmin/ templates/est/COMM_MARKETS_MONITORING/Rice/Documents/Rice_ Profile_Dec-06.pdf. Accessed 25 Sept 2018.

19. Kitano $H$, Tamura $Y$, Satoh $H$, Nagato $Y$. Hierarchial regulation of organ differentiation during embryogenesis in rice. Plant J. 1993;3:607-10.

20. Juliano BO, Bechtel DB 1985. The rice grain and its gross composition. In: Juliano BO, editor. Rice Chemistry and Technology, American Association of Cereal Chemists: Eagan, MN, USA. 1985. p. 17-57.

21. Tangpinijkul N. Rice Milling System: paper prepared for a training course on Grain Post-harvest Technology Manhattan Klongluang Hotel, Pathumthani, Thailand. 2010. https://pdfs.semanticscholar.org/ce4e/874284982e5b7603b03 73a554c786c763c8e.pdf. Accessed 25 June 2019.

22. Kennedy G, Burlingame B, Nguyen N. Nutrient impact assessment of rice in major rice-consuming countries. Food and Agriculture Organisation of the United Nations. http://www.fao.org/3/Y6159T/y6159t04.htm\#Note1. Accessed on 17 July 2019.

23. Del Rosario AR, Briones VP, Vidal AJ, Juliano BO. Composition and endosperm structure of developing and mature rice kernel. Cereal Chem. 1968:45:225-35.

24. Tanaka K, Ogawa M, Kasai Z. The Rice Scutellum. II. A comparison of scutellar and aleurone electrodense particles by transmission electron microscopy including energy-dispersive X-ray analysis. Cereal Chem. 1977; 54:684-9.

25. Juliano BO. Rice in human nutrition. FAO Food and Nutrition Series No. 21, Rome, Italy. 1993. 162.

26. Rabbani GH, Ali M. New ideas and concepts, rice bran: a nutrient dense mill-waste for human nutrition. The ORION Med. J. 2009;32(3):458-62.

27. Juliano BO. Rice: Chemistry and Technology. 2nd ed. St. Paul, MN: Am. Assoc. Cereal Chem; 1985b. p. 774.

28. Pedersen $B$, Eggum $B O$. The influence of milling on the nutritive value of flour from cereal grains. Plant foods Human Nutrition. 1983;33:267-78.

29. Ebuehi OAT, Oyewole AC. Effect of cooking and soaking on physical characteristics, nutrient composition and sensory evaluation of indigenous and foreign rice varieties in Nigeria. African Journal of Biotechnology. 2007; 6(8):1016-20.

30. Xheng $X$, Lan $Y$. Effects of drying temperature and moisture content on rice taste quality. Agricultural Engineering International: The CIGRE Journal 2007: 9. Manuscript FP07 023.

31. Eggum $\mathrm{BO}$, Juliano $\mathrm{BO}$, Maniñgat CC. Protein and energy utilization of rice milling fractions by rats. Qual. Plant. Plant Foods Hum. Nutr. 1982;31:371-6.

32. Umadevi M, Pushpa R, Sampathkumar KP, Bhowmik D. Rice- Traditional medicinal plant in India. Journal of Pharmacognosy and Phytochemistry. 2012;1(1):6-12.

33. Longvah T, Ananthan R, Bhaskarachary K, Venkaiah K. Proximate principles and dietary fibre. Hyderabad, India: Indian Food Composition Tables, National Institute of Nutrition, Department of Health Research, Ministry of Health and Family Welfare, Government of India; 2017. p. 3.

34. Sompong R, Siebenhandl-Ehn S, Linsberger-Martin G, Berghofer E. Physicochemical and antioxidative properties of red and black rice varieties from Thailand, China and Sri Lanka. Food Chemistry. 2011;124:132-40.

35. Saikia S, Dutta H, Saikia D, Mahanta CL. Quality Characterisation and estimation of phytochemicals content and antioxidant capacity of aromatic pigmented and non-pigmented rice varieties. Food Research International. 2012;46(1):334-40.

36. Eggum BO. The nutritional value of rice in comparison with other cereals. In: Proceedings, Workshop on Chemical Aspects of Rice Grain Quality, IRRI. Los Banos, Laguna, The Philippines; 1979. p. 91-111.

37. Tanaka N, Fujita N, Nishi A, Satoh H, Hosaka Y, Ugaki M. The structure of starch can be manipulated by changing the expression levels of starch branching enzyme $\mathrm{llb}$ in rice endosperm. Plant Biotechnol. J. 2004;2:207-516.

38. Juliano BO, Goddard MS. Cause of varietal difference in insulin and glucose responses to ingested rice. Qual. Plant. Plant Foods Hum. Nutr. 1986:36:35-41.

39. Tanaka Y, Resurreccion AP, Juliano BO, Bechtel DB. Properties of whole and undigested fraction of protein bodies of milled rice. Agric. Biol. Chem. 1978; 42:2015-23 
40. Choudhury NH, Juliano BO. Effect of amylose content on the lipids of mature rice grain. Phytochemistry. 1980;19:1385-9.

41. Oko AO, Onyekwere SC. Studies on the proximate chemical composition and mineral element contents of five new lowland rice varieties in Ebonyi State. Int J Biotechnology Biochemistry. 2010;6(6):949-55.

42. Lai VMF, Lu S, He WH, Chen HH. Non-starch polysaccharide compositions of rice grains with respect to rice variety and degree of milling. Food Chemistry. 2007;101(3):1205-10.

43. $\mathrm{AO} O, \mathrm{BE} \cup, \mathrm{AA} E, \mathrm{~N}$ D. Comparative analysis of the chemical nutrient composition of selected local and newly introduced rice varieties grown in Ebonyi State of Nigeria. Int J Agriculture Forestry. 2012;2(2):16-23.

44. Ramaiah K, Rao MVBN. Rice breeding and genetics ICAR science monograph 19. New Delhi, India: Indian Council of Agricultural Research; 1953.

45. Chen C-H, Yang J-C, Uang Y-S, Lin C-J. Improved dissolution rate and oral bioavailability of lovastatin in red yeast rice products. Int J Pharm. 2013; 444(1-2):18-24.

46. Yawadio R, Tanimori S, Morita N. Identification of phenolic compounds isolated from pigmented rices and their aldose reductase inhibitory activities. Food Chemistry. 2007;101(4):1616-25.

47. Sulochana S, Meyyappan RM, Singaravadivel K. Phytochemical screening and GC-MS analysis of Garudan Samba traditional rice variety. Int J Environ Agri Res. 2016;2(4):44-7.

48. Sulochana S, Meyyappan RM, Singaravadivel K. Mass spectrometry analysis of indian traditional variety "Red Kavuni" in comparison with high yielding popular variety of Tamil Nadu ADT 43 under raw and hydrothermally processed condition. Indo Am J Pharm Res. 2016;6(5):5358-63.

49. Jenkins DJA, Leeds AR, Gassell MA, Cocket B, Alberti KGM. Decrease in postprandial insulin and glucose concentrations by gaur and pectin. Ann Intern Med. 1977;86:20-3.

50. Babu DP, Bhakyaraj R, Vildhyalakshmi R. A low cost nutritious food "tempeh"- a review. World J. Dairy Food Sci. 2009;4(1):222-7.

51. Chen M-H, McClung AM, Bergman CJ. Concentrations of ligomers and polymers of proanthocyanidins in red and purple rice bran and their relationships to total phenolics, flavonoids, antioxidant capacity and whole grain color. Food Chemistry. 2016;208:279-87.

52. Tsuda T, Horio F, Uchids K, Aoki H, Osawa T. Dietary cyanidin 3-O-beta-Dglucoside-rice purple corn color prevents obesity and ameliorates hyperglycemia in mice. J. Nutr. 2003;133(7):2125-30.

53. Pojer E, Mattivi F, Johnson D, Stockley CS. The case for anthocyanin consumption to promote human health: a review. Compr. Rev. Food Sci, Food Saf. 2013;12(5):483-508.

54. Institute of Medicine (US). Standing Committee on the Scientific Evaluation of Dietary References Intakes. Dietary reference intakes for calcium, phosphorous, magnesium, vitamin D, and fluoride. Magnesium. Washington, DC: National Academies Press; 1997.

55. Shao Y, Xu F, Sun X, Bao J, Beta T. Identification and quantification of phenolic acids and anthocyanins as antioxidants in bran, embryo and endosperm of white, red and black rice kernels (Oryza sativa L.). J Cereal Sci. 2014:59:211-8.

56. Ichikawa H, Ichiyanagi T, Xu B, Yoshii Y, Nakajima M, Konishi T. Antioxidant activity of anthocyanin extract from purple black rice. J. Med. Food. 2001; 4(4):211-8.

57. Nam YJ, Nam SH, Kang MY. Cholesterol - lowering efficacy of unrefined bran oil from the pigmented black rice (Oryza sativa L cv. Suwon 415) in hypercholesterolemic rats. Food Sci. Biotechnol. 2008;17:457-63.

58. Ahuja U, Ahuja SC, Thakrar R, Singh RK. Rice- a nutraceutical. Asian AgriHistory. 2008;12(2):93-108.

59. Bhat FM, Riar CS. Health benefits of traditional rice varieties of temperate regions. Med. Aromat. Plants. 2015;4:198. https://doi.org/10. 4172/2167-0412.1000198.

60. Krishnamurthy KS. The Wealth of Susruta. Tamil Nadu, India: International Institute of Ayurveda, Coimbatore; 1991.

61. Kumar T. History of rice in India. Delhi, India: Gian Publishers; 1988.

62. Sharma PV. Classical uses of medicinal plants. Chaukhamba Vishwabharati, Varanasi. Uttar Pradesh, India. 1996:848.

63. Hedge S, Yenagi NB, Kasturiba B. Indigenous knowledge of the traditional and qualified Ayurveda practitioners on the nutritional significance and use of red rice in medications. Indian journal of traditional knowledge. 2013;12:506-11.

64. Ahuja U, Ahuja SC, Chaudhary N, Thakrar R. Red rices-past, present, and future. Asian Agri-History. 2007;11(4):291-304.
65. Arumugasamy S, Jayashankar N, Subramanian K, Sridhar S, Vijayalakshmi K. Indigenous rice varieties. Centre for Indian Knowledge System (CIKS), Chennai: Tamil Nadu India; 2001.

66. The Hindu. The Hindu Group. India: India. Indigenous rice varieties make a comeback The Hindu Group; 2018. http://www.thehindu.com/ life-and-style/food/thanals-save-our-rice-is-reviving-indigenous-ricevarieties/article22420554.ece.

67. Ahuja U, Ahuja SC, Thakrar R, Shobha Rani N. Scented rices of India. Asian Agri-History. 2008;12(4):267-83.

68. Rahman S, Sharma MP, Sahai S. Nutritional and medicinal value of some indigenous rice varieties. Indian J Traditional Knowledge. 2006;5(4):454-8.

69. Bhattacharya KR. Parboiling of rice. In: Champagne NET, editor. Rice chemistry and technology. American Association of Cereal Chemists Inc. St. Paul, Minnesota; 2004. p. 329-404.

70. Rani S, Krishnaiah K. Current status and future prospects of improving traditional aromatic rice. In: Chaudhary RC and Tran DV, editors, Specialty Rices of the World: Breeding, Production, and Marketing, FAO, Rome, Italy and Oxford IBH Publishers, India. 2001. p. 49-79.

\section{Publisher's Note}

Springer Nature remains neutral with regard to jurisdictional claims in published maps and institutional affiliations.
Ready to submit your research? Choose BMC and benefit from:

- fast, convenient online submission

- thorough peer review by experienced researchers in your field

- rapid publication on acceptance

- support for research data, including large and complex data types

- gold Open Access which fosters wider collaboration and increased citations

- maximum visibility for your research: over $100 \mathrm{M}$ website views per year

At BMC, research is always in progress.

Learn more biomedcentral.com/submissions 